\title{
Compliance of Documentation Transfer Pricing Requirements in Foreign Direct Investment Enterprises in Vietnam
}

\author{
Mai Thi Hoang Minh, Nguyen Thi Ngoc Bich \\ University of Economics of Ho Chi Minh City, Vietnam
}

\begin{abstract}
The increase of inter-boundary transactions brings a number of benefits for enterprises. However, even when benefits of transfer pricing are evident, multinational organizations still face legal challenges, including performing parts of transactions in another jurisdiction and motives of tax officials in investigating transfer pricing. This is especially true when countries do not want to lose benefits from tax collection. Therefore, many countries and organizations such as the Organization for Economic Cooperation and Development (OECD), Pacific Association of Tax Administrators (PATA), the European Union (EU), and Vietnam have introduced requirements for transfer pricing documentation to prevent transfer pricing manipulation and maintain benefits from taxes. The aim of this research was to assess the compliance of those requirements of foreign direct investment (FDI) enterprises in Vietnam. This article which is a summary of our research includes the following sections: (1) OECD guidelines of transfer pricing documentation; (2) Vietnam regulations of transfer pricing documentation; (3) results of the research; and (4) discussion and conclusion.
\end{abstract}

Keywords: transfer pricing, transfer pricing documentation compliance, foreign direct investment enterprises, Vietnam

\section{OECD Guidelines of Transfer Pricing Documentation}

OECD provided guidance for tax administrations to set rules and procedures for transfer pricing documentation for related party transactions of multinational organizations. OECD also set guidance on relevant documents that organizations need to produce to clarify the results of related transactions in accordance with ALP (Arm's Length Principle-market price principle or fair transaction principle). The guidelines have certain principles pertaining to transfer pricing documentation that tax officials and taxpayers should follow. OECD guidelines advise organizations to prove that transfer price is in accordance with ALP principle based on information available at the time of valuation (OECD, 2014). The process of consideration of appropriate transfer prices is similar to "prudent business management"-the process for reaching complex and important business decisions (Markham, 2004). Therefore, pursuant to OECD guidelines, the prudent business management principles require taxpayers to select and prepare transfer pricing documentation. When taxpayers enter into transfer pricing transactions, they are required to produce documents to ensure the compliance of ALP and maintain materials for transfer pricing audits. However, when transfer pricing transactions occur or when taxpayers prepare tax returns, taxpayers are not required to produce documentations for tax audits (Dreijer \& Samuelsson, 2006).

Mai Thi Hoang Minh, associate professor, Ph.D. in Accounting, vice dean of Principle Accounting Department, School of Accounting and Auditing, University of Economics of Ho Chi Minh City. Email: hminh09@gmail.com.

Nguyen Thi Ngoc Bich, MA, School of Accounting, University of Economics of Ho Chi Minh City. 
Tax authorities should consider the balance between demand to documentation and cost to produce those documents, in order to avoid imposing extensive costs on taxpayers to collect documentation overseas or comparable data of independent transactions, if taxpayers have plausible reasons that comparable data do not exist or costs incurred would be too high. Taxpayers are only expected to prepare and collect documentation when the documents are crucial in assessing ALP and can be obtained without too much cost. However, when a taxpayer is a subsidiary, production of information can be hard because the taxpayer has no control over the multinational corporation. In this case, tax administrators can obtain information to examine transfer price via terms and conditions in tax treaties. Tax officials should restrict documentation requirements when taxpayers file tax returns. It would be burdensome if detailed information for all inter-jurisdiction related transactions and for all members is required. When filing for tax returns, taxpayers are only required to provide relevant information that allows tax administrators to identify enterprises for tax audits afterwards (Lagerqvist \& Cheng, 2009).

\section{Regulations of Transfer Pricing in Vietnam}

\section{General Requirements for Documentations}

Pursuant to Corporate Income Tax Law of 2009, Amended Laws, Tax Administration Act of 2012, and enforcement rules, there is no official requirement for transfer pricing documentation for controlled transactions performed by affiliated parties. In general, taxpayers are required to submit tax returns, annual reports, and other documents for determining tax liability within 90 days of the end of a financial year. In addition to annual tax returns, if entities have controlled transactions, submission of information with related parties and transfer pricing methods are also required.

Based on documentation submitted by taxpayers, tax authorities may conduct an audit to ensure tax compliance. If further information is needed, tax authorities can require taxpayers to prove the accuracy of tax returns or provide additional documents such as invoices, receipts, and other information for determining tax obligation and transfer prices of controlled transactions. In addition to annual tax returns and other documents, taxpayers need to maintain all accounting records, invoices, receipts, or other relevant documents for tax audits and inspections if requested (Phan, 2014).

Requirements for transfer pricing documentations were articulated in Circular of 2010, and currently in Circular 201/2013/TT-BTC. Related parties are obliged by this Circular to disclose related party transactions in a special form, entitled Information of Related Party Transactions, and submit it together with annual corporate income tax return within 90 days of the end of the financial year.

Part A of this form requires information of related party transactions and valuation method for determining transfer price in each category of transaction. Moreover, taxpayers need to disclose total revenues or expenses and specific category of transactions in Vietnam dong (VND). This part allows alternative methods besides the five methods stated in Circular 201.

Part B of this form requires general information about related parties and their controlled transactions. Taxpayers need to disclose the names and countries of the related parties. In addition to general information about the related parties and related party transactions disclosed in annual files, taxpayers are obliged to provide information and documents in Vietnamese, relevant for determining transfer price of the controlled transactions within 30 days upon request. Depending on their clarification with tax officials, taxpayers can be granted another 30-day extension if they have sound reasons. An important note is that if taxpayers: (1) do not submit annual declaration of transfer pricing transactions; (2) do not provide appropriate documents within the 
required timing period; or (3) cannot identify reasonable comparable and relevant documents, tax authorities may make transfer pricing adjustments and impose tax penalties on taxpayers.

\section{Regulations of Transfer Pricing Documentation}

According to Circular 201 on transfer pricing in 2013, in addition to information in annual transfer pricing declaration form, entities with related party transactions are obliged to comply with the documentation regulations by providing and maintaining detailed information about affiliated parties, related party transactions, and comparable pricing methods when required by tax authorities.

The Circular requires that submitted documents be in written, either copied or original form, and conform with Vietnamese law on notarization. If electronic documents are used, they have to comply with accounting law and by-law documents relating to accounting documents. Transfer pricing documents should be in Vietnamese, and documents in foreign languages need to be translated into Vietnamese and notarized in accordance with the law on notarization (Nguyen, 2009).

According to Tax Administration Law of 2006 and Circular 201 on transfer pricing of 2013, tax authorities must secure information relating to determination of market price in related party transactions if the information cannot be obtained from public sources. The provision of information relating to taxpayers to government departments must follow Vietnamese laws. Moreover, accounting law and enforcement rules require tax authorities and other government departments to maintain accounting documents during usage time.

\section{Contemporaneous Documents}

Both Circular 66/2010/TT-BTC and Circular 201/2013/TT-BTC require taxpayers with related party transactions to prepare, maintain, and provide information and documents upon request as a basis for calculating arm's length prices. The information and documents must exist when controlled transactions occur and be updated during the performance of transactions. The Circulars require related parties to comply with the current documentation requirements, including general information on related parties to transactions, technical specification of products, contract terms, economic conditions when transactions occur, transfer price determination methods, and other relevant information of business operations of taxpayers. The documents need to be maintained in accordance with Accounting Law, Statistical Law, and Tax Laws relating to the maintenance of accounting materials. For example, Accounting Law of 2003 requires documents be maintained for at least 10 years, especially materials directly used for recording transactions and preparing annual reports. Therefore, transfer pricing documents need to be maintained at least 10 years from the date of related transactions. With current development situation of transfer pricing in Vietnam, when there is a lack of advance pricing agreement (APA) - agreement between tax authority and taxpayers—or information coordination among countries, transfer pricing documentation is currently one of the most appropriate measures against transfer pricing abuse.

Transfer pricing in Vietnam is inevitable as it is a strategic tool for corporations to reduce tax expenses and increase profits. Although opportunities for increasing profits and competitiveness exist, corporations can face legal challenges in different jurisdictions. At present, most tax audits have been conducted by General Department of Tax and some provincial tax agencies in Hanoi, Ho Chi Minh City, Binh Duong, and Dong Nai. In Vietnam, transfer pricing is quite new and sensitive. Therefore, in order to investigate the compliances of FDI companies, we took a survey with questionnaires to assess the awareness and compliance of transfer pricing documentary requirements (Do, 2012). 


\section{Results}

\section{Scope and Sample}

Questionnaires were sent to 50 FDI corporations, and 46 feedbacks were received. The questionnaires were about compliances of transfer pricing documentation regulations (see Appendix). Types of related party transactions included managerial fees, technology transfer, transportation, capital expenditures, material purchases, sales of goods to parent company, machinery and equipment leases, and trademark fees to parent company.

\section{Data Analysis}

Any strategy or policy can be successfully implemented if it was participated by board of directors on the onset. Thus, to assess the level of compliance of the Circular on transfer pricing, the questionnaires were designed to explore the boards' level of understanding, developing, and examining the compliance processes.

Although the Circular on transfer pricing significantly affects tax obligations and possible tax penalties of the company and the group, Table 1 shows that only $43.48 \%$ of the participants had an understanding of the main contents of the Circular, 39.13\% actively researched or participated in conferences held by tax authorities or consulting companies, 30.43\% participated in planning and developing compliance practices, and $17.39 \%$ directly participated in compliance audits.

Table 1

Levels of the Boards' Participation in the Circular Compliance Process

\begin{tabular}{lc}
\hline Level & Percentage (\%) \\
\hline Informed about the Circular requirements & 43.48 \\
Participating in conferences held by tax authorities & 39.13 \\
Participating in the process of planning and developing compliance practices & 30.43 \\
Examining compliance process & 17.39 \\
\hline
\end{tabular}

Note. Source: Summary from the research results.

Although the Circular is based on OECD guidelines, there are still differences between the two documents that managers should be aware of to develop relevant strategies with related party transactions. Also, tax accountants or chief accountants, rather than managers, usually participate in taxation conferences. In our view, managers with their experiences and visions would be more advantageous in assessing transfer pricing risks if they participate in the conferences held by tax authorities, hence enabling companies to comply with the regulations appropriately.

Table 2

Level of Understanding of the Contents of the Circular

\begin{tabular}{ll}
\hline Content & Percentage (\%) \\
\hline ALP & 56.52 \\
Related relationships & 34.78 \\
Related party transactions & 39.13 \\
Requirements of preparing and maintaining documentation & 39.13 \\
Requirements of related party transactions declaration & 60.67 \\
\hline
\end{tabular}

Note. Source: Summary from the research results. 
The results of Table 2 above demonstrate that understanding about the Circular was not high. According to Table 2, 56.52\% of the participants knew about ALP, 39.13\% knew about related party transactions, and 60.67\% knew about the requirements of related party transactions declaration.

To assess the level of compliance, Table 3 summarizes the main activities. Results from Table 3 illustrate that only $56.52 \%$ disclose their related party transactions. There were some reasons, for example, late submission, or no submission if no reminders from tax authorities. This practice is risky, because GNC-01/TNDN form needs to be submitted together with the annual corporate income tax returns. If companies do not submit this form, they are considered to be not in compliance with the regulations and can be penalized. However, few companies (17.39\%) develop policies about "documentary requirements" and $39.13 \%$ prepare and maintain documents for each related party transaction. It can be dangerous, especially when companies fail to provide transfer pricing determination documents and contract files with related parties when tax inspectors examine transfer pricing documents.

Table 3

Activities to Comply With the Circular

\begin{tabular}{ll}
\hline Activity & Percentage (\%) \\
\hline Disclosing related party transactions and timely submitting documents conformed with & 56.52 \\
GCN-01/TNDN form to tax administration & \\
Researching documentation requirements and comparing those with international requirements & 26.09 \\
Assessing non-compliance risks & 34.78 \\
Developing “documentation requirement” policies for the company & 17.39 \\
Preparing and maintaining documentation for each related party transaction & 39.13 \\
\hline
\end{tabular}
Note. Source: Summary from the research results.

In terms of timing and manner of transfer pricing file preparation, Table 4 shows that all companies in the sample prepared the files. In addition, $47.83 \%$ of the participants said that they prepared transfer pricing files separately for Vietnam division when needed. However, at the time of the survey, those companies had not yet prepared any related party transaction documents but assumed that the parent company would support when necessary. This practice is very risky, because a company has only 30 days to prepare supporting documents when required by tax authorities, and in reality, 30 days would not be enough to collect documents from different sources, especially for transactions occurred many years ago. However, 20 of 46 companies (43.48\%) reported that they prepared documents separately for Vietnam division and adjusted prices in accordance with current regulations. To assure the compliance, those companies used consult services of a global auditing company at the onset of the compliance application.

Table 4

Timing and Manner for Preparation of Transfer Pricing Files

\begin{tabular}{lc}
\hline Timing and manner & Percentage (\%) \\
\hline Simultaneously and globally prepared & 8.69 \\
Separately prepared and adjusted for each jurisdiction & 43.48 \\
Prepared when needed and separately for each jurisdiction & 47.83 \\
Not prepared & 0 \\
\hline
\end{tabular}

Note. Source: Summary from the research results. 
Table 5

Participation of Parent Company in Documentation Preparation

\begin{tabular}{ll}
\hline Extent & Percentage (\%) \\
\hline Not at all & 13.04 \\
Small extent & 34.78 \\
Moderate extent & 26.09 \\
Great extent & 26.09 \\
\hline
\end{tabular}

Note. Source: Summary from the research results.

Most companies have developed policies for transactions with independent parties. To avoid tax penalty risks, companies need to understand the differences in tax base and valuation base in business activities and have appropriate adjustments in financial reports. The results indicate that although the Circular came into effect for a certain period of time, the "wait and see" phenomenon was popular in many companies. Most companies focused on declaration of normal transactions instead of on evidence for sound transfer prices in related party transactions. According to the results of Table 5, only $13.04 \%$ of the companies did not receive supports from the parent company, indicating that many corporations had well researched the transfer pricing rules and were well prepared to deal with tax audit mechanisms in different jurisdictions.

It can be seen from Table 6 that the main purposes of documentary preparation were to deal with tax controlling mechanisms (39.13\%) and mitigate risks in a tax examination (47.83\%). Only $8.7 \%$ of the participants considered documentary preparation as opportunities for tax planning in order to comply with the regulations and maximizing profits by reducing tax liabilities.

Table 6

Purposes of Documentary Preparation

\begin{tabular}{lc}
\hline Purpose & Percentage (\%) \\
\hline To maintain consistency & 13.04 \\
To mitigate risks & 47.83 \\
To deal with controlling mechanisms & 39.13 \\
To minimize non-compliance costs & 21.74 \\
To take opportunity of tax planning & 8.7 \\
To have strategy or settlement—as the case may be & 13.04 \\
To follow the policies of the group & 26.09 \\
\hline
\end{tabular}

Note. Source: Summary from the research results.

Table 7 shows that $69.57 \%$ of the companies considered transfer pricing documentary as important and $21.74 \%$ as very important. Only those who did not use consulting services, e.g., of global auditing companies, considered transfer pricing documentary as unimportant. For those companies, the participation of the parent company was limited.

Table 7

Importance of Transfer Pricing Documentary

\begin{tabular}{lc}
\hline Level & Percentage (\%) \\
\hline Unimportant & 0 \\
Relatively important & 8.69 \\
Important & 69.57 \\
Very important & 21.74 \\
\hline
\end{tabular}

Note. Source: Summary from the research results. 


\section{Discussions and Conclusion}

As stated in the results, $69.57 \%$ and $21.74 \%$ of participants considered transfer pricing documentary as important and very important, respectively; only those who did not use consult services and received limited compliance support from parent company considered transfer pricing documentary as unimportant. Due to the effectiveness of transfer pricing Circular in 2010 in Vietnam, few, if any, tax audits for transfer pricing documentary compliance have been conducted, or only conducted in serious cases. Hence, some corporations have underestimated the importance of transfer pricing documentation. Note that, according to the Circulation, tax authorities can adjust tax obligations occurred within the last five years, and collect tax amount occurred over five years if supporting documents are inappropriate.

The compliance of transfer pricing documentary of FDI enterprises was not high. Although most companies (69.57\%) considered transfer pricing documentary as important and $60.87 \%$ of companies were aware of the requirements, only $56.52 \%$ disclosed their related party transactions. This is a paradox as there were many companies which did not make the practice although transfer pricing documentary is important in minimizing taxation risks.

It can be argued that in many cases, the sound in-house documents for transactional comparison are limited, resulting in the impossibility of compliance. If Vietnam administrators want to facilitate the operations of multinational corporations in Vietnam, documents before or after controlled transactions should be accepted as long as they follow market rule. Moreover, taxpayers should not be required to prove the best method used. Therefore, transfer pricing files should include documents as a basis for adopting pricing method, not necessary documents for comparison with other methods. In cases where there are no or not enough comparative in-house documents, Vietnamese tax authorities should accept evidences from overseas in foreign languages (PATA, 2013).

Given our discussions, we also recommend that Ministry of Finance and General Department of Taxation consider abolition of inappropriate corporate income tax exemptions solely based on industry or province, amendment and improvement of transfer pricing legal framework harmonizing with policies in other countries in order to minimize opportunistic behaviors, amendment of thin capitalization rules, improvement of tax administration mechanism towards companies with related transactions with companies in tax paradises, that is, countries with low tax rates.

In addition, to improve the effectiveness of transfer pricing inspection and audit and to enhance the tax authority's capacity, Ministry of Finance and General Department of Taxation should coordinate with EU Commission, OECD, and World Bank in Vietnam to conduct comprehensive transfer pricing trainings for specialized transfer pricing team in General Department of Taxation and provincial tax officers who directly administer transfer pricing compliance, and develop information database on profit margins of independent enterprises in high transfer pricing risk industries, supporting tax officials in analyzing transfer pricing activities.

\section{References}

Do, N. L. (2012). Solutions to ensure compliance with transfer pricing regulations of FDI enterprises in Vietnam (Master dissertation, University of Economics of Ho Chi Minh City).

Dreijer, C., \& Samuelsson, C. (2006). Documentation requirements on transfer pricing: A comparative study of international guidelines. Retrieved from http://www.diva-portal.org/smash/get/diva2:4241/FULLTEXT01.pdf 
Lagerqvist, J., \& Cheng, Y. (2009). Documentation within transfer pricing: A case study. Retrieved from http://www.diva-portal.org/smash/get/diva2:228175/FULLTEXT01.pdf

Markham, M. (2004). Complying with Australian and PATA transfer pricing documentation rules-A Sisyphean task? Revenue Law Journal, 14(1), 161-187.

Nguyen, T. (2009). Transfer pricing: The Vietnamese system in the light of the OECD guidelines and the systems in certain developed and developing countries. Jönköping: Jönköping International Business School.

OECD. (2014). Guidance on transfer pricing documentation and country-by-country reporting. Retrieved from http://www.oecd-ilibrary.org/taxation/guidance-on-transfer-pricing-documentation-and-country-by-country-reporting_97892 64219236-en

PATA. (2013). Pacific Association of Tax Administrators (PATA) transfer pricing documentation package. Retrieved from https://www.nta.go.jp/kohyo/katsudou/shingi-kenkyu/kokusai020617/pdf/01.pdf

Phan, H. (2014). Transfer pricing (teaching documents).

\section{Appendix: Survey for Documentation Regulations of Transfer Pricing}

Date: $/ 2014$

Please note that your answers will be strictly confidential.

Part 1: Please Answer the Following Questions

1. How does your company know about the documentation regulations of transfer pricing?

2. In your opinion, are there risks inherent in the documentation regulations of transfer pricing? If there are, please provide some examples.

3. How long does it take to prepare transfer pricing documentation?

4. What kind of transactions among related companies does your company have?

5. Which transactions are popular among related companies?

6. How much does it cost to comply with the documentation regulations of transfer pricing?

7. Does your company consider non-compliance enforcements?

8. Do you have any recommendation for the documentation regulations of transfer pricing in Vietnam? 


\section{Part 2: Please Select the Most Appropriate Answer for Each Question}

Guidance: Circle your answer

1. What is the timing and manner of preparing documentation in your company?

(a) Simultaneously and globally prepared

(b) Separately prepared and adjusted for each jurisdiction

(c) Prepared when needed and separately for each jurisdiction

(d) Not prepared

2. What is the main purpose of documentation preparation?

(a) To maintain consistency

(b) To mitigate risks

(c) To cope with controlling mechanisms

(d) To minimize non-compliance costs

(e) To take opportunity of tax planning

(f) To have strategy or settlement-as the case may be

(g) To follow the policies of the group

3. How do you think of the documentation?

(a) Unimportant

(b) Relatively important

(c) Important

(d) Very important

4. To what extent does the parent company participate in the process of preparing documentation?
(a) Not at all
(b) Small extent
(c) Moderate extent
(d) Great extent

5. To what extent does the board of directors participate in the process?
(a) Informed about the documentation regulations
(b) Participating in conferences held by tax authorities
(c) Participating in the process of planning and developing compliance practices
(d) Auditing compliance process

6. What does your company know about the regulations?
(a) ALP
(b) Related relationships
(c) Related transactions
(d) Requirements of preparing and storing documentation
(e) Requirements of disclosing related transactions 
7. What does your company do to comply with the regulations?

(a) Disclose related transactions and submit documents in a timely manner

(b) Research the documentation requirements and make a comparison with international requirements

(c) Assess non-compliance risks

(d) Develop “documentation requirement” policies for the company

(e) Prepare and maintain documentation for each related transaction 